\title{
Micronodular thymoma with lymphoid stroma の二切除例
}

\author{
大村 征司, 政井 恭兵, 加勢田 馨 \\ 朝倉 啓介，菱田 智之，淺村 尚生
}

\begin{abstract}
要 旨
Micronodular thymoma with lymphoid stroma（リンパ性間質を伴う小結節性胸腺腫，以下 MNTLS）は胸腺腫の $1.4 \%$ を占める比較的稀な胸腺腫の一型である.今回我々は二例の MNTLS を経験した。症例 1. 60 歳女性. 胸部 CT で前縦隔に $17 \mathrm{~mm}$ 大の結節を指摘され, 胸腔鏡下前縦隔腫瘍切除術を施行した. 症例 2.70 歳女性. 胸部 CT で前縦隔に $18 \mathrm{~mm}$ 大の結 節を指摘され，胸腔鏡下前縦隔腫瘍切除術を施行した。いずれの腫瘍も B リンパ球が豊富な間質を背景に, 腫瘍細胞が敷石 状に広がっており, MNTLS と診断した. MNTLSは, 針生検や迅速診断ではAB 型胸腺腫や胸腺リンパ滤胞過形成と誤診さ れる可能性もあるが，過去の報告では予後は良い疾患であり症例 1 においては術後 4 年, 症例 2 においては術後 1 年 6 カ月 経過した現在も無再発生存中である. 文献的考察を加えて報告する.
\end{abstract}

索引用語 : 胸腺, 胸腺腫, リンパ性間質を伴う小結節性胸腺腫 thymus, thymoma, micronodular thymoma with lymphoid stroma

はじめに

MNTLS は胸腺腫の $1.4 \%$ を占める比較的稀な胸腺腫 の一型である.MNTLS は紡錘形から卵円形の腫瘍細胞 を含む複数の上皮性結節が，上皮性細胞を認めない豊富 なリンパ球に富むリンパ性間質に区画された腫瘍と定義 される1).リンパ性間質には肧中心を伴うリンパ濾胞が見 られることから, 胸腺リンパ濾胞過形成 (thymic follicular hyperplasia）や上皮細胞の類似性と豊富なリンパ球 の存在から $\mathrm{AB}$ 型胸腺腫との鑑別が必要となることがあ る.今回我々は緩徐に増大する MNTLSを二例経験し た. 迅速結果ではいずれも $\mathrm{AB}$ 型胸腺腫の診断であり, 永久病理結果と異なる結果であった。 これを文献的考察 を加えて報告する。

慶應義塾大学医学部外科学 (呼吸器)

原稿受付 2020年12月 4 日

原稿採択 2021年 3 月 9 日
症例

\section{症例 1}

症 例：60 歳女性.

主 訴：特になし。

現病歴: 某年 6 月, 健診での胸部 Computed Tomography (CT) で前縦隔に $17 \mathrm{~mm}$ 大の結節を指摘され 当科を受診された. 胸部造影 CT では前縦隔に軽度の造 影効果を示す境界明瞭な $17 \mathrm{~mm}$ 大の充実性結節を認め た. 胸腺腫が疑われ手術の方針となった。

家族歴：特になし.

既往歴：甲状腺腺腫，腎血管筋脂肪腫.

喫煙歴：特になし。

初診時現症：身体所見で異常所見は認めなかった.

初診時検査所見：抗アセチルコリン抗体 $<0.2 \mathrm{nmol} /$

L, CEA 1.6 ng/ml, CA19-9 20.4 U/ml であり, その他に 異常所見を認めなかった.

初診時レントゲン：異常所見は認めなかった.

初診時画像所見：CT では前縦隔に境界明瞭, 辺縁整, 内部均一で軽度の造影効果を示す $1.7 \mathrm{~cm}$ 大の充実性結 節を認めた (Fig. 1). Positron Emission Tomography- 


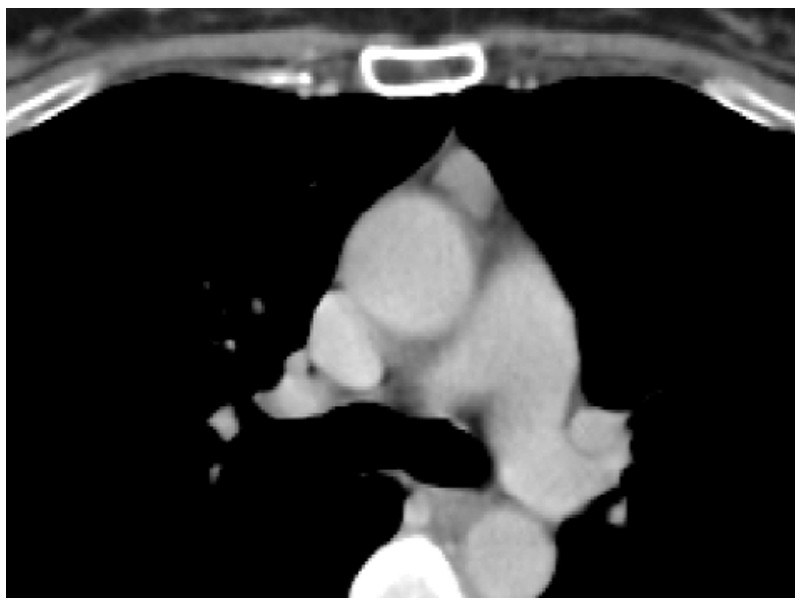

Fig. 1 Case 1: Chest computed tomography showed a well-marginated $17-\mathrm{mm}$ round nodule with homogeneous enhancement in the anterior mediastinum.

Computed Tomography (PET-CT) では Standardized Uptake Value max (SUV max) 1.5 と明らかな集積は認め なかった，その他，明らかな転移を疑わせる所見を認め なかった. Magnetic Resonance Imaging (MRI) では T1 強調像, T2 強調像いずれも中等度の高信号を認めた.

手 術：右側臥位で胸腔鏡下前縦隔腫瘍切除術を施行 した．第 8 肋間前腋窩線でカメラポートを挿入した後, 第 4 肋間前腋窩線と第 6 肋間後腋窩線にポート孔を作成 した。病変は被膜に包まれ播種や隣接臟器浸潤は認めな かった．腫瘍を周囲の胸腺組織と合わせて切除し, 腫瘍 を摘出した。迅速病理診断では $\mathrm{AB}$ 型胸腺腫の診断で あった。

病理組織学的所見 : 弱拡大では腫瘍細胞が小結節性, 地図状に存在する領域（好酸性領域）とそれを取り囲む ように小型リンパ球が目立つ領域（好塩基性領域）とが 混在していた (Fig. 3A，B)。強拡大では好酸性領域では 腫瘍細胞は，核小体が明瞭な紡錘形の腫瘍細胞が胞巣状 増生を示していた，好塩基性領域では腫瘍細胞は認めら れず，リンパ滤胞を伴う部分も認められた，免疫染色で は pankeratin が腫瘍結節と一致して陽性となり, リンパ 間質領域では pankeratin 陽性細胞は認めなかった（Fig. 3C)。リンパ球間質領域には CD20 陽性のB B リンパ球の 集簇を認めた (Fig. 3D). 以上より胸腺腫の一組織型であ る MNTLS と診断した。腫瘍には一部被膜欠損を認め WHO classification pT2N0M0 Stage II, Masaoka II 期で あった。

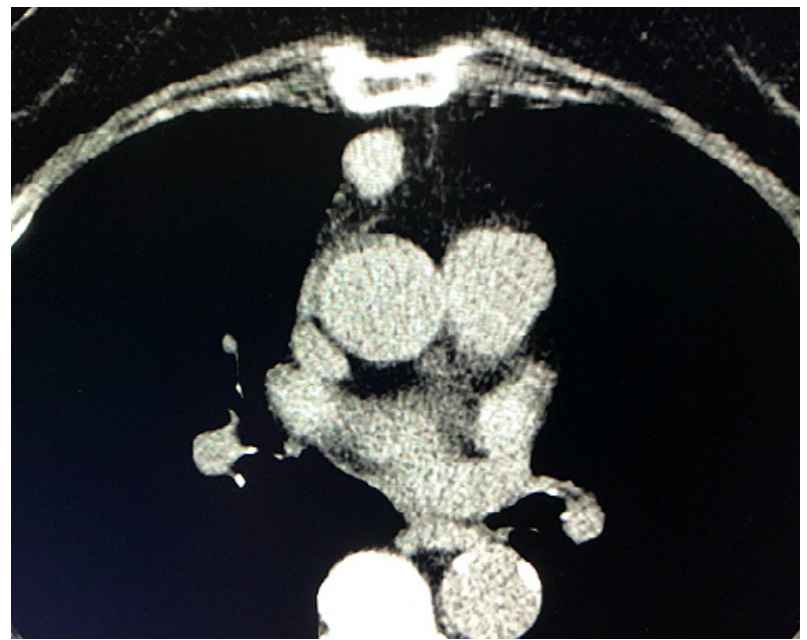

Fig. 2 Case 2: Chest computed tomography showed a well-marginated $18-\mathrm{mm}$ round nodule in the anterior mediastinum.

術後経過：経過は良好で術後 4 年を経過した現在も無 再発生存中である。

\section{症例 2}

症 例 : 70歳女性.

主 訴：特になし。

現病歴：某年 9 月, 健診での CT 検查で前縦隔に 1.8 $\mathrm{cm}$ 大の結節を指摘され当科を受診された，胸腺腫が疑 われ手術の方針となった。

家族歴：特になし

既往歴：高血圧.

喫煙歴：10 本 $/$ 日 $\times 30$ 年.

初診時現症：身体所見で異常所見は認めなかった。

初診時検査所見：抗アセチルコリン抗体 $<0.2 \mathrm{nmol} /$

L, CEA $3.7 \mathrm{ng} / \mathrm{ml}$, その他に異常所見を認めなかった. 初診時レントゲン：異常所見は認めなかった

初診時画像所見：CT では前縦隔に境界明瞭, 辺縁整, 内部均一な $18 \mathrm{~mm}$ 大の充実性結節を認めた（Fig. 2). PET-CT では SUVmax 2.55 の集積を認めた，その他，明 らかな転移を疑わせる所見を認めなかった。

手 術：右側臥位で胸腔鏡下前縦隔腫瘍切除術を施行 した．第 8 肋間前腋窩線でカメラポートを挿入し，後側 方第 5 肋間で約 $2 \mathrm{~cm}$ の皮切を置きミニループリトラク ターを装着した. 第 4 肋間後腋窩線にも $11.5 \mathrm{~mm}$ のポー 卜を追加した，病変は被膜に包まれ播種や隣接臟器浸潤 は認めなかった，腫瘍を周囲の胸腺組織と合わせて切離 し，腫瘍を摘出した，迅速病理診断では $\mathrm{AB}$ 型胸腺腫の 

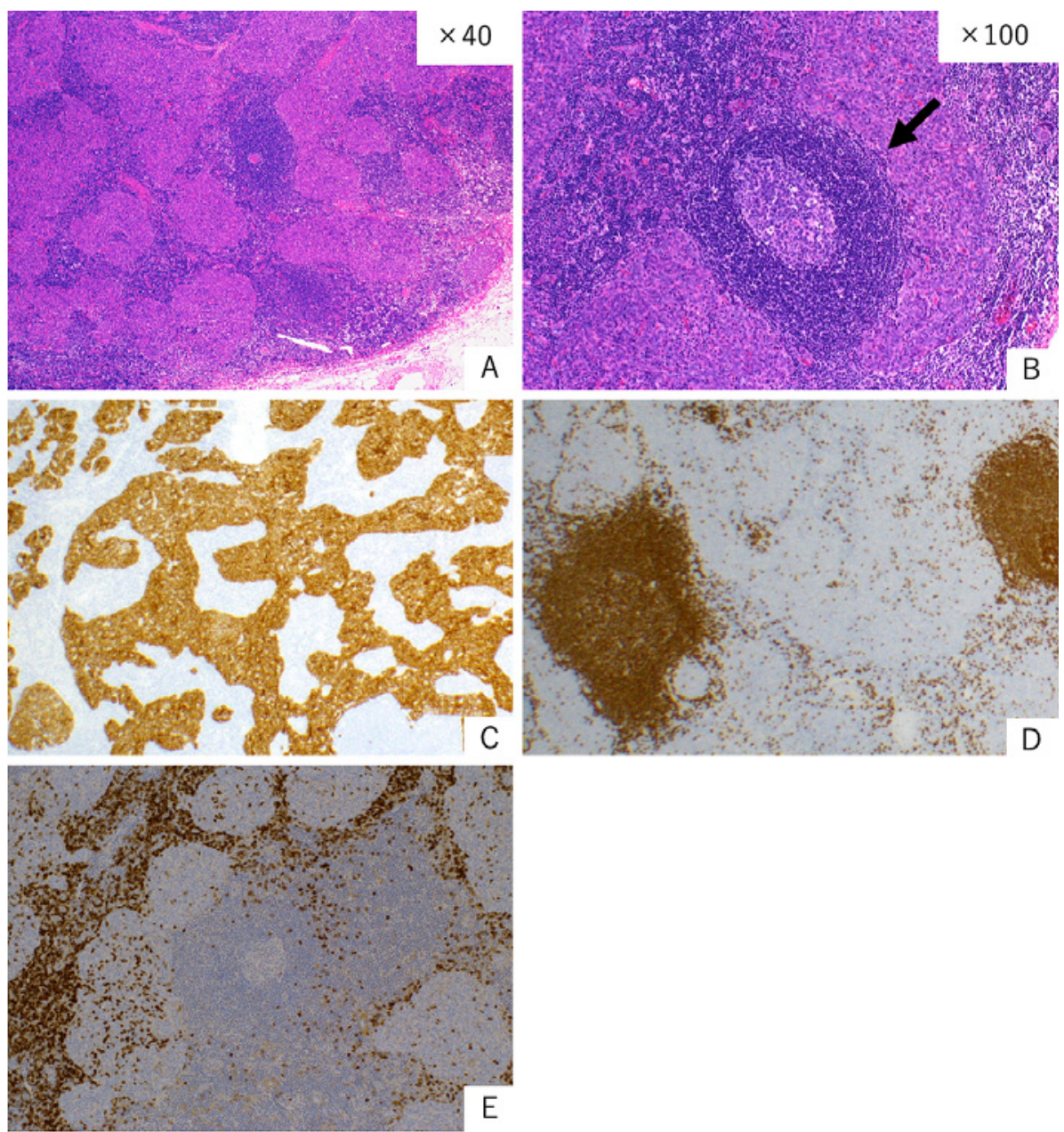

Fig. 3 This figure shows hematoxylin and eosin staining of the surgical specimen of Case 1 (A and B). Histopathological findings of the nodule revealed separation by an abundant lymphoid stroma, showing a basophilic area (A). Histopathological findings of the nodule revealed lymphoid follicles with germinal centers in an abundant lymphoid stroma (B).

Immunohistochemical staining showed that the nodule was positive for pankeratin in the field of tumor cells (C). Immunohistochemical staining showed that the lymphoid stroma was positive for CD20 (D).

Immunohistochemical staining showed that the lymphoid stroma was positive for CD20 (E).

診断であった。

病理組織学的所見：弱拡大では豊富なリンパ球が増殖 する部分（好塩基性領域）と核小体の明瞭な楕円形〜紡 錘形核を持つ腫瘍細胞が地図状に混在する部分（好酸性 領域) が混在していた (Fig. 4A，B). 強拡大では, 好酸 性領域の腫瘍細胞は核小体が明瞭で楕円形〜紡錘形核を 持っていた。 また, 免疫染色では, pankeratin が腫瘍結 節と一致して陽性となり, リンパ性間質領域では pankeratin 陽性細胞は認めなかった(Fig. 4C)。 またリンパ性
間質領域に存在するリンパ球の多くは CD20 陽性の B 細胞であった (Fig. 4D). 以上より胸腺腫の一組織型であ るMNTLS と診断した. 腫瘍には一部被膜欠損を認め WHO classification pT2N0M0 Stage II, Masaoka II 期で あった。

術後経過：経過は良好で術後 1 年 6 力月を経過した現 在も無再発生存中である. 


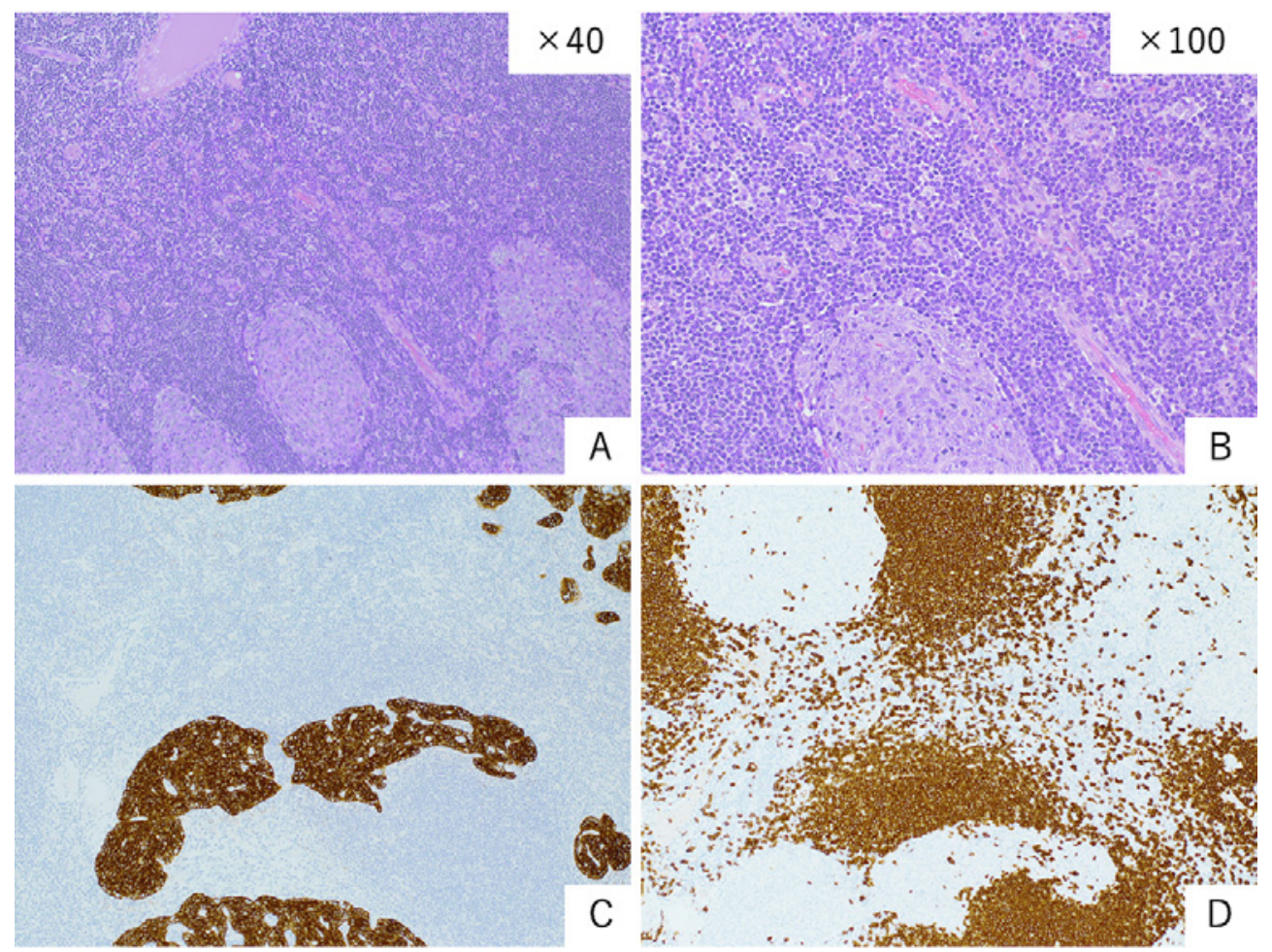

Fig. 4 This figure shows hematoxylin and eosin staining of the surgical specimen of Case 2 (A and B). Histopathological findings of the nodule revealed separation by an abundant lymphoid stroma, showing a basophilic area (A). Immunohistochemical staining showed that the nodule was positive for pankeratin in the field of tumor cells (C). Immunohistochemical staining showed that the lymphoid stroma was positive for CD20 (D).

\section{考察}

MNTLS は 1999 年に Suster と Moran により報告さ れた疾患 ${ }^{2)}$ でる.WHO の定義によると MNTLS は紡錘 形から卵円形の腫瘍細胞を含む複数の上皮性結節が, 上 皮性細胞を認めないリンパ性間質に区画された腫瘍と定 義される1).リンパ性間質には時にリンパ濾胞を含む. 胸 腺腫全体の $1.4 \%$ と稀な組織型であり,これまでの報告に よると MNTLS は 41〜80 歳（中央值 64.5 歳, 平均值 71 歳）で男女比は男性：女性=1.5：1 とわずかに男性に多 いとされている1). また, 重症筋無力症との合併例は稀と されており ${ }^{1)}$, 検索し得た限りではPanらが 2 例 ${ }^{3)}$, Ströbel らは 1 例 ${ }^{4)}$ 重症筋無力症との合併例を報告して いるのみである。多くの MNTLS は限局性であり $62 \%$ が Stage I, 36\% が Stage II である ${ }^{1)}$. 今回報告する 2 症例 は 60 歳と 70 歳の女性であり, 共に Stage II であった. 共に重症筋無力症の合併は認めなかった.

MNTLS と鑑別を要する疾患として AB 型胸腺腫が挙
げられる. Suster らは，MNTLS とAB 型胸腺腫はとも に $\mathrm{A}$ 型胸腺腫に類似した腫瘍細胞の領域とリンパ球豊 富な領域が混在しているがMNTLS はリンパ球豊富な 領域に腫瘍細胞は認めなく, $\mathrm{AB}$ 型胸腺腫はリンパ球豊 富な領域に B 型胸腺腫とよく似た多角形の上皮性腫瘍 細胞が存在することが特徴であるとしている ${ }^{2)}$.また,リ

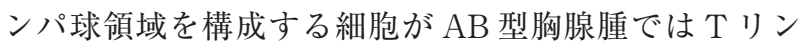
パ球であるのに対し MNTLS では肧中心を伴うリンパ 滤胞をしばしば認め, B リンパ球が主体である ${ }^{2,5.6)}$. 本症 例においても術中迅速病理検査では，いずれ $\mathrm{AB}$ 型胸腺 腫の診断であった，迅速診断においては正常リンパ球と 胸腺上皮性由来の小型異型リンパ球の鑑別が困難であ り，MNTLS は発生頻度が低いことからも AB 型胸腺腫 と診断される傾向にあると考えられる。同様に鑑別を要 する疾患として胸腺リンパ濾胞過形成が挙げられる.

Shimosato らによると, 胸腺リンパ滤胞過形成は肧中心 を伴うリンパ滤胞がみられることや胸腺上皮の増生をみ ることもあるとされるため時に鑑別が必要であるとされ 
Table 1 Cases of micronodular thymoma with lymphoid stroma

\begin{tabular}{|c|c|c|c|c|c|c|}
\hline Literature & $\mathrm{N}$ & $\mathrm{M} / \mathrm{F}$ & Age & $\begin{array}{l}\text { Size } \\
(\mathrm{cm})\end{array}$ & Stage & Follow-up \\
\hline Suster, et al. 2) & 8 & $4 / 4$ & $48-76$ & $4-10$ & I-II & Alive for $12-84$ months \\
\hline Ströbel, et al. 4) & 18 & $11 / 7$ & $47-79$ & NA & I-II & Alive for 24-190 months \\
\hline Rieker, et al. 5) & 1 & $0 / 1$ & 80 & 7 & I & Died of cardiac failure \\
\hline $\mathrm{El}$, et al. $\left.{ }^{6}\right)$ & 2 & $1 / 1$ & $62-64$ & $7-8$ & I-II & Alive for $17-24$ months \\
\hline Ishikawa, et al. 8) & 6 & $4 / 2$ & $56-74$ & $1.2-5$ & I-IIa & Alive for $36-93$ months \\
\hline Mende, et al. 9) & 1 & $1 / 0$ & 45 & 3.5 & I & Alive for 12 months \\
\hline Kim, et al. ${ }^{10)}$ & 1 & $1 / 0$ & 73 & 5.1 & I & Alive for 12 months \\
\hline Zhu, et al. ${ }^{11)}$ & 1 & $0 / 1$ & 76 & 3.7 & I & Alive for 24 months \\
\hline Chen, et al. 12) & 1 & $1 / 0$ & 79 & 10.7 & IIa & Alive for 6 months \\
\hline Mneimneh, et al. ${ }^{13)}$ & 4 & $2 / 2$ & $51-73$ & $3-5.5$ & IIa & Alive for $1-72$ months \\
\hline Yu, et al. ${ }^{14)}$ & 1 & $0 / 1$ & 62 & 2.8 & I & Alive for 4 months \\
\hline Lyu, et al. ${ }^{15)}$ & 1 & $1 / 0$ & 55 & 7 & I & Alive for 32 months \\
\hline This article & 2 & $0 / 2$ & $60-70$ & $1.7-1.8$ & I & Alive for $14-40$ months \\
\hline
\end{tabular}

る7). しかし, 上皮の柵状配列など, 正常胸腺の構造は保 たれ結節状の増生は認めないとする点で MNTLS と異 なる.

本症例のように術中迅速病理検査と永久病理検査で結 果が異なる理由として, 術中迅速検査や針生検では十分 な検体量が得られていない可能性があることが挙げられ る. 検体部位によっては他の胸腺腫や, 胸腺リンパ滤胞 過形成と誤診される可能性があることを考慮しておかな ければならない。

MNTLSの発生においては，不明な点も多いが Ishikawa が Langerhans 細胞と樹状細胞が小腫瘍結節 とリンパ球間質のリンパ滤胞の形成に重要な役割を果た していると報告している8 . 本症例でも症例 1 において腫 瘍結節内に扔いて, Langerhans 細胞が認められ (Fig. $3 \mathrm{E}$ )，過去の報告を支持するものであった。 Ishikawa は腫瘍結節内で腫瘍細胞もしくは腫瘍細胞に 関連する抗原から抗原刺激を受けた Langerhans 細胞が リンパ球間質に遊走し，その Langerhans 細胞がリンパ 球間質内で樹状細胞に分化した後ナイーブ T 細胞に抗 原提示することで, 抗原特異的な $\mathrm{B}$ 細胞が増殖しリンパ 滤胞を形成するという可能性を報告しているが，不明な 点も多く今後の症例集積による十分な検討が必要であろ う.

MNTLS の治療については Ströbel らが報告したよう に, 大部分が限局性の病変であり, 予後良好な疾患であ ることから他の胸腺腫と同様に胸腺腫切除もしくは拡大 胸腺全摘術による完全切除が基本であるとしている4).
我々の症例でも術前で胸腺腫を疑い，他臓器の浸潤傾向 がないことに加え， $2.0 \mathrm{~cm}$ 以下の腫瘍であったため胸腔 鏡手術により完全切除が可能であった。腫瘍の局在や腫 瘍径より鏡視下手術，小開胸手術，胸骨正中切開による 腫瘍摘出など柔軟な対応が必要であろう.

1999 年〜2015 年に術後経過を追跡することができた MNTLS の自験例を合わせた 47 症例を下記に示す（Table 1$)^{2,46.8-15)}$. 腫瘍による死亡例の報告はなく, 1 例は腫瘍 とは関連のない死亡, 46 例は 1 カ月〜190 カ月の followup 期間中, 無再発生存中であり, 過去の文献を比較して も予後は良い疾患であると考えられる。

しかしながら, Tateyamaらが報告した 11 例の MNTLS 症例の中で, 無再発生存しているものの明暸な 核小体をもち, 細胞分裂像を伴う低分化な MNTLS も報 告されている ${ }^{16)}$. この様に予後は良好と考えられるが高 悪性度の腫瘍なども報告されている様に不明な点も多く 長期成績を検討するには今後さらなる症例の集積が必要 であろう。

\section{謝 辞}

病理学的な専門知識をもとに原稿作成にご協力いただ いた慶應義塾大学病院病理診断部林雄一郎先生に心か ら感謝の意を表します。

\section{利益相反}

本論文について申告する利益相反はない. 


\section{文献}

1. Travis WD, Brambilla E, Burke AP, Marx A, Nicholson AG. WHO classification of tumours of the Lung, Pleura, Thymus and Heart. $4^{\text {th }}$ ed. Lyon: IARC; 2015.

2. Suster S, Moran CA. Micronodular thymoma with lymphoid B-cell hyperplasia: clinicopathologic and immunohistochemical study of eighteen cases of a distinctive morphologic variant of thymic epithelial neoplasm. Am J Surg Pathol 1999; 23: 955-62.

3. Pan CC, Chen WY, Chiang H. Spindle cell and mixed spindle/lymphocytic thymomas: an integrated clinicopathologic and immunohistochemical study of 81 cases. Am J Surg Pathol 2001; 25: 111-20.

4. Ströbel P, Marino M, Feuchtenberger M, Rouzière AS, Tony HP, Wulbrand U, et al. Micronodular thymoma: an epithelial tumour with abnormal chemokine expression setting the stage for lymphoma development. J Pathol 2005; 207: 72-82.

5. Rieker RJ, Aulmann S, Schnabel PA, Sack FU, Otto HF, Mechtersheimer G, et al. Cystic thymoma. Pathol Oncol Res 2005; 11: 57-60.

6. El MF, Braham E, Ayadi A, Ismail O, Kilani T. Micronodular thymoma with lymphoid stroma: report of two cases and particular association with thymic lymphoid hyperplasia in one case. Pathology 2006; 38: 586-8.

7. Shimosato Y, Mukai K, Matsuno Y, editors. AFIP Atlas of Tumor Pathology, $4^{\text {th }}$ Series, Fascicle 11 - Tumors of Mediastinum, 1st ed. Silver Spring: ARP Press; 2010: 2769.

8. Ishikawa Y, Tateyama H, Yoshida M, Takami K, Matsuguma H, Taniguchi T, et al. Micronodular thymoma with lymphoid stroma: an immunohistochemical study of the distribution of Langerhans cells and mature dendritic cells in six patients. Histopathology 2015; 66: 300-7.

9. Mende S, Moschopulos M, Marx A, Laeng RH. Ectopic micronodular thymoma with lymphoid stroma. Virchows Arch 2004; 444: 397-9.

10. Kim NR, Lee JI, Ha SY. Micronodular thymoma with lymphoid stroma in a multilocular thymic cyst: a case study. Korean J Pathol 2013; 47: 392-4.

11. Zhu P, Yan F, Ao Q. Langerhans cells proliferation in ectopic micronodular thymoma with lymphoid stroma: a case report. Int J Clin Exp Pathol 2014; 7: 7262-7.

12. Chen CW, Chuang SS, Pan ST. Micronodular thymoma with lymphoid stroma diagnosed with core needle biopsy: a case report. Anal Quant Cytopathol Histpathol 2015; 37: 206-10.

13. Mneimneh WS, Gökmen-Polar Y, Kesler KA, Loehrer PJ Sr, Badve S. Micronodular thymic neoplasms: case series and literature review with emphasis on the spectrum of differentiation. Mod Pathol 2015; 28: 1415-27.

14. Yu M, Meng Y, Xu B, Zhao L, Zhang Q. Ectopic micronodular thymoma with lymphoid stroma in the cervical region: a rare case associated with Langerhans cells proliferation. Onco Targets Ther 2016; 9: 4317-22.

15. Lyu BB, Yao ZG, Wang Z. Micronodular thymoma with lymphoid stroma: report of a case. Zhonghua Bing Li Xue Za Zhi 2017; 46: 197-8.

16. Tateyama H, Saito Y, Fujii Y, Okumura M, Nakamura K, Tada $\mathrm{H}$, et al. The spectrum of micronodular thymic epithelial tumours with lymphoid B-cell hyperplasia. Histopathology 2001; 38: 519-27. 


\title{
Two cases of resection of micronodular thymoma with lymphoid stroma
}

\author{
Seiji Omura, Kyohei Masai, Kaoru Kaseda \\ Keisuke Asakura, Tomoyuki Hishida, Hisao Asamura
}

Division of Thoracic Surgery, Department of Surgery, Keio University School of Medicine, Tokyo, Japan

Micronodular thymoma with lymphoid stroma (MNTLS) is rare, accounting for $1.4 \%$ of the total cases of thymoma. We report two surgical cases of MNTLS. Case 1: The patient was a 60-year-old woman who had a 17-mm nodule in the anterior mediastinum that was revealed by chest computed tomography during a medical checkup. We performed video-assisted thoracoscopic thymectomy. Case 2: The patient was a 70-year-old woman who had an 18-mm nodule in the anterior mediastinum that was also revealed by chest computed tomography during a medical checkup. We performed video-assisted thoracoscopic thymectomy. Both resected tumors were well-defined and homogenously white in color. Histopathological findings of the tumors revealed separation by an abundant lymphoid stroma with a field of tumor cells. Immunohistochemical staining showed that the tumors were positive for pankeratin in the field of tumor cells. The histopathological diagnosis was MNTLS. The long-term outcomes after the resection of MNTLS were good in previous reports. Case 1 has survived without recurrence for four years, and Case 2 has survived without recurrence for one year and six months.

(C) The Japanese Association for Chest Surgery (JACS) 